\title{
Exogenous enzyme on in vitro gas production and ruminal fermentation of diet containing high level of concentrate ${ }^{1}$
}

\author{
Enzimas exógenas sobre produção de gás e fermentação ruminal in vitro de dieta \\ contendo alta nível de concentrado
}

\author{
FREIRIA, Lucien Bissi da ${ }^{2 *}$;ERVOUDAKIS, Joanis Tilemahos ${ }^{2}$; PAULA, Nelcino \\ Francisco de ${ }^{2}$; CABRAL, Luciano da Sival ${ }^{2}$; TEDESCHI, Luis Orlindo ${ }^{3}$; SILVA, Pedro \\ Ivo Jose Lopes da Rosa e ${ }^{2}$; MELO, Alan Carlos Barbosa ${ }^{4}$; POSSAMAI, Adriano Jorge ${ }^{2}$
}

\footnotetext{
${ }^{1}$ Universidade Federal de Mato Grosso, Cuiabá, Mato Grosso, Brasil, work funded by CAPES.

${ }^{2}$ Universidade Federal de Mato Grosso, Faculdade de Agronomia e Zootecnia, Programa de PósGraduação em Ciência Animal, Cuiabá, Mato Grosso, Brasil.

${ }^{3}$ Texas A\&M University System, Texas A\&M University, Department Of Animal Science, College Station, Estados Unidos.

${ }^{4}$ Universidade Estadual Paulista, Pós-Graduação em Ciência e Tecnologia Animal, Dracena, São Paulo, Brasil.

*Endereço para correspondência: lucienbissi@hotmail.com
}

\section{SUMMARY}

Exogenous enzyme preparations (fibrolytic activity (FIB), 0, 0.6, 1.2, 1.8, and $2.4 \mathrm{mg} / \mathrm{ml}$ liquid volume incubated; amylolytic activity (AMZ), 0, 0.05, 0.10, 0.15, and $0.20 \mathrm{mg} / \mathrm{ml}$ liquid volume incubated; proteolytic activity (PRO), 0, 0.05, 0.10, 0.15, and $0.20 \mathrm{mg} / \mathrm{ml}$ liquid volume incubated) were incubated in vitro. Their fermentation effects were assessed based on accumulated gas production, kinetic parameters, and fermentation profile using the technique of gas fermentation. Ruminal liquid was obtained from two rumen cannulated Santa Inês sheep, fed a diet with roughage-to-concentrate ratio of 20:80. Accumulated gas production was during $96 \mathrm{~h}$ of incubation, measured at 18 different times. After incubation, $\mathrm{pH}$, dry matter degradability (DMD), organic matter in vitro digestibility (OMD), metabolisable energy (ME), partitioning factor $\left(\mathrm{PF}_{96}\right)$, gas yield $\left(\mathrm{GY}_{24}\right)$, short chain fatty acids (SCFA), and microbial protein production (MCP) were evaluated. Increasing FIB dose linearly decreased $(\mathrm{P}<0.05)$ lag time without affecting others kinetic parameters. However, FIB increased the accumulated gas production, resulting in improved DMD, OMD, $\mathrm{ME}, \mathrm{GY}_{24}$ and SCFA. The addition of AMZ decreased linearly $(\mathrm{P}<0.05)$ lag time and increased $(\mathrm{P}<0.05)$ gas production on initial times of incubation without altering the fermentation profile. The inclusion of PRO did not affect $(\mathrm{P}>0.05)$ the evaluated parameters. The addition of these exogenous enzyme preparations with fibrolytic activity altered ruminal fermentation in vitro of diets containing high levels of concentrates.

Keywords: amylolytic, degradability, fibrolytic, proteolytic

\section{RESUMO}

Preparações de enzimas exógenas (atividade fibrolítica (FIB); 0,0;0,6;1,2;1,8 e 2,4 mg/ml do volume de líquido incubado; atividade amilolítica (AMZ); 0,0; 0,05; 0,10;0,15 e 0,20 $\mathrm{mg} / \mathrm{ml}$ do volume de líquido incubado; atividade proteolítica (PRO); 0,0;0,05; 0,10; 0,15 e $0,20 \mathrm{mg} / \mathrm{ml}$ do volume de líquido incubado) incubado in vitro. Os efeitos de fermentação foram avaliados com base na produção de gás acumulado, parâmetros cinéticos e, perfil de fermentação usando a técnica de fermentação in vitro. O líquido ruminal foi obtido de dois ovinos Santa Inês canulados no rúmen, alimentados com dieta relação volumoso:concentrado de 20:80. A produção de gás acumulada foi durante $96 \mathrm{~h}$ de incubação, mensurados em 18 tempos diferentes. Após a incubação foi avaliado $\mathrm{pH}$, 
digestibilidade da material seca (DMS), digestibilidade da material orgânica (DMO), energia metabolizável (EM), fator de partição $\left(\mathrm{FP}_{96}\right)$, rendimento de gás $\left(\mathrm{RG}_{24}\right)$, ácidos graxos de cadeia curta (AGCC), e produção de proteína microbiana (PPM). O incremento de doses linear de FIB diminuiu $(\mathrm{P}<0,05)$ o lag time sem afetar outros parâmetros cinéticos. No entanto, adição de FIB aumentou a produção de gás acumulado, resultando em incremento na DMS, DMO, EM, $\mathrm{RG}_{24}$ e AGCC. A adição de AMZ diminuiu linearmente $(\mathrm{P}<0,05)$ lag time $\mathrm{e}$ incrementou $(\mathrm{P}<0,05)$ produção de gás nos tempos iniciais de incubação sem alterar o perfil de fermentação. A inclusão de $\mathrm{PRO}$ não afetou $(\mathrm{P}>0,05)$ os parâmetros avaliados. As adições de preparações enzimáticas exógenas com atividades fibrolíticas alteram fermentação ruminal in vitro de dieta de alta níveis de concentrado.

Palavras-chaves: amilolítica, degradabilidade, fibrolítica, proteolítica

\section{INTRODUCTION}

Modern feedlot diets are balanced by taking into account many different nutrients (COLE et al., 2012). Studies have aimed to maximize the use of feed ingredients at the ruminal level. There are still big unknowns to be explored regarding the inclusion of exogenous enzymes in feedlot diets.

Exogenous enzymes can promote improvements on ruminal kinetics parameters (ELGHANDOUR et al., 2013), and nutrient digestibility (YANG et al., 2011; TANG et al., 2008), and can allow the manipulation of final products from fermentation (TRICARICO et al., 2005; 2008) without changing the composition of the diet being fed. This occurs due to mechanisms that still have to be better understood (YANG et al., 2011; RANILLA et al., 2008), how differences in enzyme activity, application rate and composition, mode and time of enzymatic contact, ruminal activity in vitro and enzyme stability in this environment, and enzyme-food specificity (BEAUCHEMIN et al., 2004; ADESOGAN, 2014).

The initial evaluation of these mechanisms can be established through the in vitro gas production technique, using semiautomatic methods (MAURÍCIO et al., 1999; THEODOROU et al., 1994) or computerized methods (TEDESCHI et al., 2009). This technique evaluates the ruminal kinetics parameters such as fermentation rate, extension and profile (ELGHANDOUR et al., 2013; VÁRADYOVÁ et al., 2005), in a short period of time (MAURÍCIO et al., 2003), which allows to understand the effects of including exogenous enzyme on ruminant diets, helping nutritionists to identify ideal enzyme preparations and effective dosages before creating profitable commercial products for the ruminant production industry (EUN \& BEAUCHEMIN, 2007).

The objectives of this study were to evaluate dosages of exogenous enzyme preparations with fibrolytic, amylolytic, and proteolytic activity on diets containing high levels of concentrates through gas production, kinetic parameters, and fermentation profile using the technique of in vitro fermentation.

\section{MATERIAL AND METHODS}

The diet used on in vitro incubations was a typical diet containing high levels of concentrates, for our conditions in which roughage-to-concentrate ratio is about 20:80, and the diet is composed of corn silage, ground corn, soybean meal, soybean hulls, and mineral mixture (Table 1). 
Table 1. Formulation and chemical composition of the feedlot diet

\begin{tabular}{lc}
\hline Ingredients, g/kg DM & diet \\
\hline Corn silage & 200.0 \\
Ground corn & 540.0 \\
Soybean meal & 120.0 \\
Soybean hulls & 105.0 \\
Mineral mix ${ }^{1}$ & 35.0 \\
\hline \multicolumn{2}{c}{} \\
\hline DM, g/kg & 685.1 \\
OM, g/kg da MS & 941.4 \\
CP, g/kg da MS & 127.4 \\
NDF, g/kg da MS & 265.0 \\
\hline${ }^{\top}$ Mineral mix = security levels: calcium 198g; phosphoro 60g; sodium 117g; magnesium 5.1g; sulfur 12.6g; iodine \\
17.7mg; iron 425mg; selenium 10.4mg; cobalt 80mg; manganese 527mg; fluorine 600mg; copper 1000mg and zinc \\
3000mg.
\end{tabular}

Roughage and concentrate samples were oven dried at $55^{\circ} \mathrm{C}$ for $72 \mathrm{~h}$, grounded in a Wiley mill using $1 \mathrm{~mm}$ screen and stored for further determination of chemical components and in vitro gas production.

Five dosages of each enzyme preparation were evaluated according to its activity. For the fibrolytic preparation (FIB; Fibrozyme, Alltech Inc., Nicholasville, $\mathrm{KY}$ ), the dosages were $0,0.6,1.2,1.8$, and $2.4 \mathrm{mg} / \mathrm{ml}$ liquid volume incubated. For the amylolytic preparation (AMZ; Amaize, Alltech Inc., Nicholasville, KY), the dosages were $0,0.05,0.10,0.15$, and $0.20 \mathrm{mg} / \mathrm{ml}$ liquid volume incubated. For the proteolytic preparation (PRO; VEG PRO, Alltech Inc., Nicholasville, KY), the dosages were $0,0.05,0.10,0.15$, and $0.20 \mathrm{mg} / \mathrm{ml}$ liquid volume incubated. These levels were set according to manufacturer's daily intake recommendations for beef cattle, and extrapolated for in vitro incubation according to Tricarico et al. (2005), calculating the enzyme amount in relation to liquid medium (concentration $\mathrm{mg} / \mathrm{ml}$ liquid volume incubated), not necessarily relating to the enzyme-to-substrate ratio in a practical diet.
Ruminal fluid was collected from two Santa Inês sheep (60 a $70 \mathrm{~kg}$ body weight) fitted with permanent rumen cannula and fed a TMR diet with 20:80 roughage:concentrate ratio (same diet incubate in vitro), previously adapted for $15 \mathrm{~d}$. The animals were kept in individual sheltered pens, equipped with feeding trough and drinker.

Rumen fluid was collected from each animal before the morning feeding, filtered through four cheese cloth layers and stored in an insulated bottle without leaving empty spaces, and immediately send to Animal Nutrition Laboratory/ Federal University of Mato Grosso. For each $125 \mathrm{ml}$ amber glass flask, we weighted $0.5 \mathrm{~g}$ of diet, and enzyme preparations added according previously cited dosages (mg enzyme/ ml liquid). All methodological procedures used should be right supported by Mauricio et al. (1999). Sequentially, $40 \mathrm{ml}$ of buffer solution were added for each flask according to Goering \& Van Soest (1970), followed by $10 \mathrm{ml}$ of particle-free rumen fluid, resulting in a proportion inoculum:buffer of 1:4 (v/v). Flasks were immediately closed with rubber caps and 
aluminium ring and maintained at $39{ }^{\circ} \mathrm{C}$ in constant agitation.

We used a total of 126 flasks in triplicates for each enzymatic dosage and for blanks (only ruminal fluid and buffer solution) in three runs in different weeks, being incubated for $96 \mathrm{~h}$. Produced gas volume was registered on times $1,2,3,4,56,8$, $10,12,18,24,30,36,42,48,60,72$, and $96 \mathrm{~h}$ of incubation utilizing the semiautomatic reading technique described by Theodorou et al. (1994) and Mauricio et al. (1999). At the end of each incubation, flasks were opened to measure $\mathrm{pH}$ ( $\mathrm{pH}$ meter, $\mathrm{pH}$ METER TC2 , Tecnal), and were filtered to obtain the non-fermentable residue, for the determination of disappeared substrate.

At the end of incubation, the contents of each bottle were filtered through quantitative paper filter (Whatman no. 54, $11 \mathrm{~cm}$, particle retention from $20-25 \mu \mathrm{m}$ ). Fermentation residues were dried at $105^{\circ} \mathrm{C}$ overnight to estimate DM disappearance with loss in weight after drying being the measure of undegradable DM.

The feed samples were submitted to chemical analysis in accordance with the procedures of AOAC (1990) for dry (DM, method \# 930.15), ash (method \# 924.05), and crude protein (CP, method \#
984.13). The aNDFom were determined by methods of Van Soest et al. (1991). In NDF analysis, samples were treated with a heat stable alpha amylase, without addition of sodium sulphite and exclusive of residual ash.

The fibrolytic enzyme preparation containing xylanase and cellulase activities (Fibrozyme TM, Alltech Inc., Nicholasville, KY, USA) were previously checked for enzymatic activities suppliers guarantee levels, in accordance with the methodologies proposed by Colombatto \& Beauchemin (2003). Enzymatic activity of the amylolytic preparation is $600 \mathrm{FAU} / \mathrm{g}$, and was previously checked for guarantee levels according to methodologies proposed by Biely et al. (1985) and Tricarico et al. (2008). Enzymatic activity of the proteolytic preparation is a minimum of protease $7.500 \mathrm{u} \mathrm{HUT} / \mathrm{g}$ and a minimum of cellulase of $45 \mathrm{u} \mathrm{CMCU} / \mathrm{g}$, and was previously checked according to methodologies proposed by Food Chemicals Codex (2010).

Gas production kinetic parameters $(\mathrm{ml} / \mathrm{g}$ DM) were estimated using NLIN option of SAS (version 9.3), according to the model proposed by Schofield et al. (1994):

$$
V_{t}=V_{1} /\left(1+\exp \left(2-4_{1}^{* *}(t-L)\right)\right)+V_{2} /\left(1+\exp \left(2-4_{2}^{* *}(t-L)\right)\right)
$$

where $\mathrm{V}_{\mathrm{t}}$ is the total gas volume at time $t ; \mathrm{V}_{1}$ is asymptotic cumulative gas volume $(\mathrm{ml} / \mathrm{g} \mathrm{DM}), \quad k_{1}$ is the rate $(/ \mathrm{h})$ parameters for the first pool (rapid), and $\mathrm{V}_{2}$ and $k_{2}$ is corresponding parameters for the second pool (slow); L is the latency, and $t$ is incubation time (h). It was used the interactive process of Marquardt algorithm for adjustments.

The metabolisable energy ( $\mathrm{ME}, \mathrm{MJ} / \mathrm{kg}$ $\mathrm{DM}$ ) and in vitro organic matter digestibility (OMD, g/kg OM) were estimated according to Menke et al. (1979) as:

$$
\begin{gathered}
E M=2.20+0.136 \mathrm{GP}(\mathrm{ml} / 0.2 \mathrm{~g} \mathrm{MS})+0.057 \mathrm{CP}(\mathrm{mg} / 0.2 \mathrm{~g} \mathrm{MS}) \\
O M D=148.8+8.89 \mathrm{GP}+4.5 \mathrm{CP}(\mathrm{mg} / 0.2 \mathrm{~g} \mathrm{MS})+0.651 \mathrm{ash}(\mathrm{mg} / 0.2 \mathrm{~g} \mathrm{MS})
\end{gathered}
$$


where GP is the gas production in $\mathrm{ml}$ from $200 \mathrm{mg}$ of dry sample, incubated for $24 \mathrm{~h}$.

The partitioning factor at $96 \mathrm{~h}$ of incubation $\left(\mathrm{PF}_{96} ; \mathrm{a}\right.$ measure of fermentation efficiency) was calculated as the ratio of DM degradability in vitro (DMD, mg) to the volume (ml) of GP at
$96 \mathrm{~h}$ (i.e., DMD/total gas production $\left(\mathrm{GP}_{96}\right)$ ) according to Blümmel et al. (1997).

Gas yield $\left(\mathrm{GY}_{24}\right)$ was calculated as the volume of gas (ml gas/g DM) produced after $24 \mathrm{~h}$ of incubation divided by the amount of DMD (g) according to Salem et al. (2014) as:

$$
\text { Gas Yield }\left(G Y_{24}\right)=G P(m l / g D M) / D M D(g)
$$

A short chain fatty acid concentration (SCFA) was calculated according to Getachew et al. (2002) as:

$$
\text { SCFA }(\mathrm{mmol} / \mathrm{g} \mathrm{DM})=0.0222 \text { GP }-0.00425
$$

where GP is the $24 \mathrm{~h}$ net gas production $(\mathrm{ml} / \mathrm{g}$ DM). Microbial CP biomass production was calculated according to Blümmel et al. (1997) as:

$$
M C P(m g / g D M)=D M D(m g)-(G P \times 2.2 m g / m l)
$$

where GP is the $24 \mathrm{~h}$ net gas production $(\mathrm{ml} / \mathrm{g} \quad \mathrm{DM})$, and $2.2 \mathrm{mg} / \mathrm{ml}$ is a stoichiometric factor which expresses $\mathrm{mg}$ of $\mathrm{C}, \mathrm{H}$ and $\mathrm{O}$ required for the production of SCFA gas associated with production of $1 \mathrm{ml}$ of gas.

Data from in vitro gas production and fermentation parameters were analysed in a completed randomized design using the MIXED procedure of SAS (version 9.3). The statistical model was:

$$
Y_{i j}=\mu+E N Z_{i}+\varepsilon_{i j}
$$

where $Y_{i j}$ is the dependent variable, $\mu$ the overall mean, $\mathrm{ENZ}_{\mathrm{i}}$ is the effect of enzyme level, and $E_{i j}$ is the residual error term.

The levels of enzymatic preparations were considered fixed effects. Before the statistical analyses, it was obtained the means from data of each week, which was used as experimental unit (UDÉN et al., 2012). The LSMEANS option was used to generate individual means for each treatment. Orthogonal contrasts were used to partition specifically the effects of enzyme levels on linear, quadratic, cubic and quartic. Cubic and quartic effects were not significant. In all analysis, significances were declared at $\mathrm{P}<0.05$.

\section{RESULTS AND DISCUSSION}

Addition of FIB linearly decreased $(\mathrm{P}<0.05)$ latency $(L)$, but there were no differences $(\mathrm{P}>0.05)$ in the degradation rates $k_{1}$ and $k_{2}$, and the volume of gas production from rapid and slow degrading pools, $\left(V_{l}\right.$ and $\left.V_{2}\right)$, respectively (Table 2 ). Increasing the dose of FIB linearly increased $(\mathrm{P}<0.05)$ the accumulated gas production (GP, $\mathrm{ml} / \mathrm{g} \mathrm{DM}$ ) for evaluated times (Table 2). 
Table 2. In vitro rumen gas kinetics and cumulative gas production in response to fibrolytic enzyme dose ( $\mathrm{mg} / \mathrm{ml}$ liquid volume incubated)

\begin{tabular}{lccccccccccc}
\hline Enzyme & \multicolumn{4}{c}{ Gas production parameters ${ }^{\mathrm{a}}$} & \multicolumn{4}{c}{ In vitro gas production (ml/g DM) } \\
\hline Dosage & $V_{1}$ & $k_{1}$ & $L$ & $V_{2}$ & $k_{2}$ & $\mathrm{GP}_{6}$ & $\mathrm{GP}_{12}$ & $\mathrm{GP}_{24}$ & $\mathrm{GP}_{48}$ & $\mathrm{GP}_{72}$ & $\mathrm{GP}_{96}$ \\
\hline 0.0 & 136.8 & 0.093 & 2.36 & 154.4 & 0.023 & 76.5 & 149.2 & 215.7 & 267.6 & 287.3 & 291.2 \\
0.6 & 140.7 & 0.093 & 2.15 & 167.5 & 0.025 & 83.3 & 159.1 & 230.8 & 285.0 & 305.1 & 308.2 \\
1.2 & 148.0 & 0.095 & 1.82 & 177.5 & 0.024 & 93.4 & 173.0 & 246.8 & 304.2 & 323.1 & 325.4 \\
1.8 & 148.9 & 0.096 & 1.50 & 183.5 & 0.024 & 100.9 & 180.8 & 255.1 & 311.0 & 328.8 & 332.3 \\
2.4 & 158.4 & 0.096 & 1.34 & 189.1 & 0.025 & 110.7 & 195.3 & 271.5 & 330.0 & 347.5 & 347.5 \\
SEM & 9.282 & 0.005 & 0.273 & 18.158 & 0.004 & 2.925 & 2.609 & 15.579 & 19.259 & 15.708 & 13.244 \\
\hline P-value & & & & & & & & & & & $*$ \\
\hline Linear & $\mathrm{NS}$ & $\mathrm{NS}$ & $* *$ & $\mathrm{NS}$ & $\mathrm{NS}$ & $* *$ & $* *$ & $*$ & $*$ & $*$ & $* *$ \\
Quadratic & $\mathrm{NS}$ & $\mathrm{NS}$ & $\mathrm{NS}$ & $\mathrm{NS}$ & $\mathrm{NS}$ & $\mathrm{NS}$ & $\mathrm{NS}$ & $\mathrm{NS}$ & $\mathrm{NS}$ & $\mathrm{NS}$ & $\mathrm{NS}$ \\
\hline
\end{tabular}

$V_{l}$ is the volume for the rapid pool (first pool); $k_{1}$ is rate for the rapid pool (first pool); L is the latency; $\mathrm{V}_{2}$ is the volume for the slow pool (second pool); $k_{2}$ is the rate for the slow pool (second pool).

NS: Not significant, $* \mathrm{P}<0.05$ and $* * \mathrm{P}<0.01$

The comportment of the gas production curve with include FIB is presented in Figure 1a. The DMD, OMD, ME, GY 24 and SCFA $(\mathrm{P}<0.05$, linear effect $)$ increased in response to FIB dose, and $\mathrm{PF}_{96}$ decreased $(\mathrm{P}<0.05$, linear effect $)$, but not effect $(\mathrm{P}>0.05) \mathrm{pH}$ and $\mathrm{MCP}$ (Table 3).

The rumen fluid used in the present work was from animals fed with high concentrate diets (20:80) it may be inferred that there was reduced proportion of fibrolytic microorganisms (and their enzymes) according observed by Tajima et al. (2001), caused by reduced amount of substrate (fibrous carbohydrates) as well low rumen $\mathrm{pH}$ (in this study $\mathrm{pH}$ of the rumen fluid was $5.53 \pm 0,081)$.

Thus, the addition of fibrolytic enzymes increased the digestion of the fibre, as evidenced by increase on total gas production. This is enzymes promote greater hydrolytic capacity of ruminal liquid (BEAUCHEMIN et al., 1999; 2004), with a possible better synergistic relationship between exogenous enzymes and ruminal microbiota (NSEREKO et al., 2002), due to the interaction occurs via cross-feeding, for release of polysaccharides readily utilized by microorganisms (TRICARICO et al., 2008).

The animals kept in intensive production systems where diets have high concentrate proportions, adding fibrolytic enzymes can increase the fibre digestion in the rumen, with possibility increase microbial protein synthesis and VFA production, favourable increasing in animal production. Russell et al. (1992) proposed that the yield of fibrolytic microbial population of the rumen is reduced by $2.5 \%$ for each reduction unit forage fibre, when its percentage is lower than $20 \%$, as a result of reduction in population growth on $\mathrm{pH}$ lower than 6.0. Although the percentage of roughage and the energy contribution from fibre carbohydrates in diets containing high levels of concentrates is small, several authors (RUSSELL, 2002; KRAUSE et al., 2003) highlight the need to use strategies that could improve fibre digestion in these conditions, in order to increase the energy supply and microbial protein synthesis. 

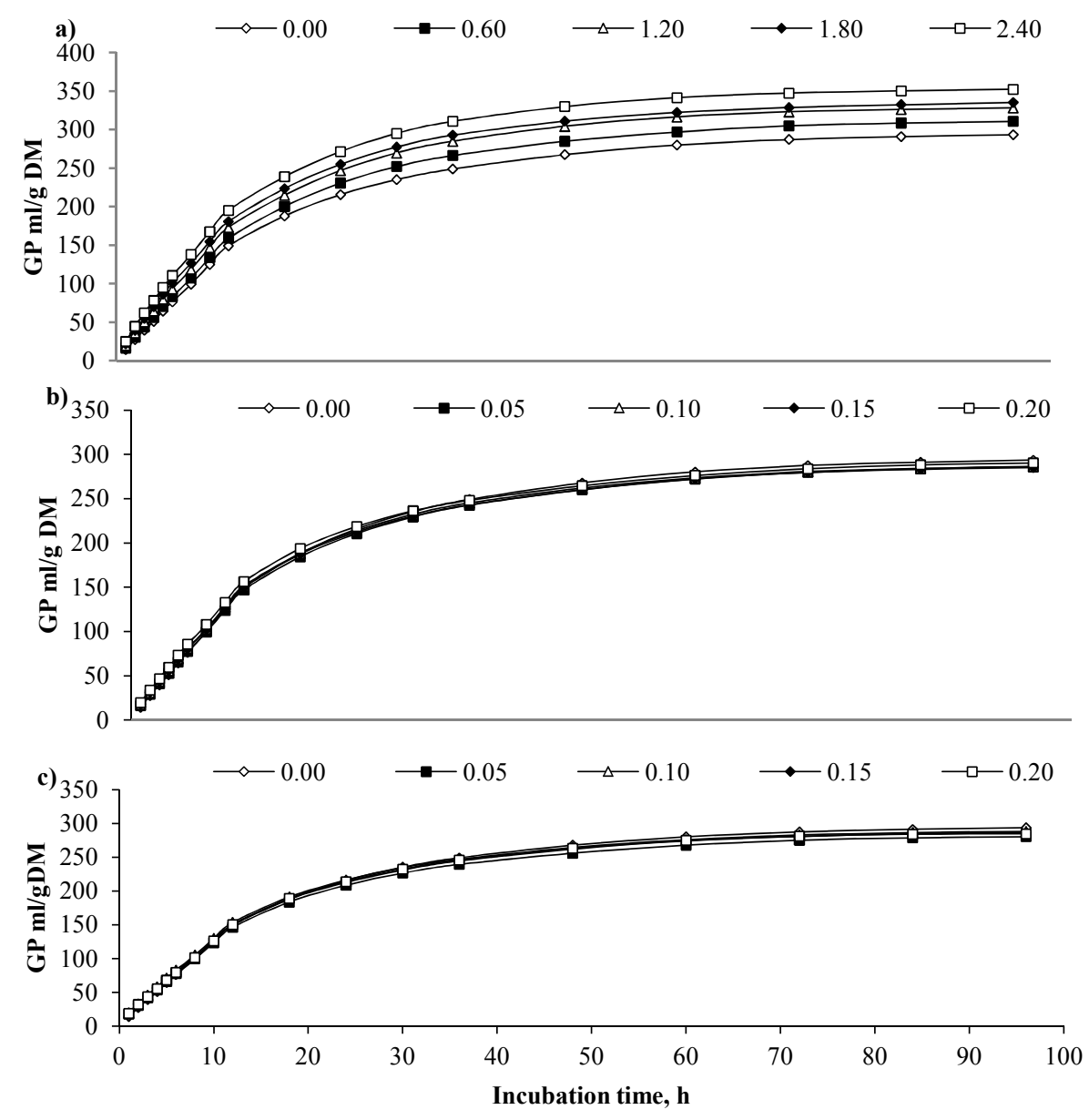

Figure 1. Cumulative gas production profiles ( $\mathrm{ml}$ gas/g DM) from in vitro fermentation of tree exogenous enzyme at five doses ( $\mathrm{mg} / \mathrm{ml}$ liquid volume incubated): a Fibrolytic enzyme, b Amylolytic enzyme and c Proteolytic enzyme

Table 3. In vitro rumen fermentation profile in response to exogenous enzyme dose ( $\mathrm{mg} / \mathrm{ml}$ liquid volume incubated $)^{1}$

\begin{tabular}{|c|c|c|c|c|c|c|c|c|}
\hline Enzyme dosage & $\mathrm{pH}$ & DMD & OMD & $\mathrm{ME}$ & PF96 & GY24 & SCFA & $\mathrm{MCP}$ \\
\hline & \multicolumn{8}{|c|}{ Fibrolytic Enzyme } \\
\hline 0.0 & 6.60 & 817 & 0.616 & 9.5 & 2.8 & 263 & 4.78 & 342 \\
\hline 0.6 & 6.60 & 852 & 0.642 & 9.9 & 2.8 & 270 & 5.12 & 344 \\
\hline 1.2 & 6.57 & 857 & 0.668 & 10.4 & 2.6 & 287 & 5.47 & 314 \\
\hline 1.8 & 6.57 & 873 & 0.682 & 10.6 & 2.6 & 292 & 5.66 & 311 \\
\hline 2.4 & 6.57 & 887 & 0.709 & 11.0 & 2.5 & 306 & 6.02 & 289 \\
\hline SEM & 0.026 & 13.948 & 0.027 & 0.423 & 0.080 & 14.415 & 0.344 & 22.443 \\
\hline \multicolumn{9}{|l|}{ P-value } \\
\hline Linear & NS & $* *$ & $*$ & $*$ & $*$ & $*$ & $*$ & NS \\
\hline Quadratic & NS & NS & NS & NS & NS & NS & NS & NS \\
\hline
\end{tabular}

${ }^{1}$ DMD is dry matter degradability (mg/g DM); OMD is in vitro organic matter digestibility (g/g DM incubated at 24h); ME is metabolisable energy (MJ/kg DM); PF96 is the partitioning factor at $96 \mathrm{~h}$ of incubation (mg DM:ml gas); GY24 is gas yield at $24 \mathrm{~h}$ (ml gas/g DMD); SCFA is short chain fatty acids (mmol/g DM); MCP is microbial CP production $(\mathrm{mg} / \mathrm{g} \mathrm{DM})$

NS: Not significant, ${ }^{*} \mathrm{P}<0.05$ and ${ }^{* *} \mathrm{P}<0.01$. 
Thus, the use of fibrolytic enzymes presents the potential of promoting improvement in fiber digestion in animals fed high concentrates diets. The importance improvement fiber digestion fed high concentrates diets are represented for positive impact OMD, Hales et al. (2017) observed that reduce of $10 \%$ in fiber digestion, could decrease $2 \%$ in OMD, condition of use corn oil in high concentrates diets. Montgomery et al. (2008), affirm that reduce OMD infer microbial efficiency and minor flow $\mathrm{N}$ microbial for intestinal.

In high concentrates diets even there is participate of fiber have aim ruminal health, for rumination stimulation , equilibrium of $\mathrm{pH}$, keep ruminal movements, and reduces acidosis risks (NAGARAJA \& TITGEMEYER, 2007), an increase fiber digestion, that not reduce your paper in provide ruminal health, could provide condition acceptable for major performance animal.

However, it is fundamental to evaluate the economic impact of the use of fibrolitic enzymes in diets containing high levels of concentrates.

Addition of $\mathrm{AMZ}$ declined L linearly $(\mathrm{P}<0.05)$ without modifying $(\mathrm{P}>0.05)$ others gas production parameters $\left(k_{1}, k_{2}\right.$, $V_{l}$, and $V_{2}$, Table 4). However, increasing AMZ, linearly increased $(\mathrm{P}<0.05)$ initial $\mathrm{GP}, \mathrm{GP}_{6}$ and $\mathrm{GP}_{12}$, without altering others times (Table 4).

Table 4. In vitro rumen gas kinetics and cumulative gas production in response to amylolytic and proteolytic enzyme dose ( $\mathrm{mg} / \mathrm{ml}$ liquid volume incubated)

\begin{tabular}{|c|c|c|c|c|c|c|c|c|c|c|c|}
\hline \multirow{2}{*}{$\begin{array}{l}\text { Enzyme } \\
\text { Dosage } \\
\end{array}$} & \multicolumn{5}{|c|}{ Gas production parameters ${ }^{a}$} & \multicolumn{6}{|c|}{ In vitro gas production (ml/g DM) } \\
\hline & $V_{1}$ & $k_{1}$ & $L$ & $V_{2}$ & $k_{2}$ & $\mathrm{GP}_{6}$ & $\mathrm{GP}_{12}$ & $\mathrm{GP}_{24}$ & $\mathrm{GP}_{48}$ & $\mathrm{GP}_{72}$ & $\mathrm{GP}_{96}$ \\
\hline & \multicolumn{11}{|c|}{ Amylolytic Enzyme } \\
\hline 0.00 & 136.8 & 0.093 & 2.36 & 154.3 & 0.023 & 76.5 & 149.2 & 215.7 & 267.6 & 287.3 & 291.2 \\
\hline 0.05 & 137.4 & 0.090 & 2.06 & 146.6 & 0.022 & 77.5 & 147.0 & 210.6 & 259.9 & 279.7 & 284.0 \\
\hline 0.10 & 140.6 & 0.089 & 1.84 & 143.4 & 0.022 & 80.9 & 151.2 & 213.9 & 261.9 & 280.5 & 284.0 \\
\hline 0.15 & 140.8 & 0.088 & 1.77 & 143.2 & 0.022 & 80.5 & 149.8 & 212.3 & 260.4 & 279.9 & 283.9 \\
\hline 0.20 & 148.7 & 0.086 & 1.51 & 140.1 & 0.022 & 85.5 & 156.4 & 218.6 & 264.6 & 283.7 & 288.8 \\
\hline SEM & 6.118 & 0.006 & 0.200 & 5.655 & 0.003 & 2.446 & 2.117 & 12.475 & 14.506 & 10.846 & 7.768 \\
\hline \multicolumn{12}{|l|}{ P-value } \\
\hline Linear & NS & NS & ** & NS & NS & $*$ & * & NS & NS & NS & NS \\
\hline Quadratic & NS & NS & NS & NS & NS & NS & NS & NS & NS & NS & NS \\
\hline & \multicolumn{11}{|c|}{ Proteolytic Enzyme } \\
\hline 0.00 & 136.8 & 0.093 & 2.36 & 154.4 & 0.023 & 76.5 & 149.2 & 215.8 & 267.6 & 287.3 & 291.1 \\
\hline 0.05 & 139.1 & 0.086 & 1.79 & 139.6 & 0.022 & 78.2 & 146.2 & 208.5 & 256.0 & 275.2 & 278.8 \\
\hline 0.10 & 146.1 & 0.086 & 1.58 & 140.5 & 0.022 & 83.1 & 153.5 & 216.3 & 264.6 & 283.1 & 286.6 \\
\hline 0.15 & 141.7 & 0.085 & 1.62 & 143.0 & 0.021 & 81.3 & 150.4 & 212.5 & 261.8 & 280.6 & 284.7 \\
\hline 0.20 & 141.4 & 0.086 & 1.75 & 142.6 & 0.022 & 79.7 & 150.3 & 213.8 & 263.0 & 280.9 & 284.0 \\
\hline SEM & 5.805 & 0.005 & 0.233 & 6.134 & 0.003 & 2.152 & 1.376 & 12.662 & 13.812 & 10.931 & 8.287 \\
\hline \multicolumn{12}{|l|}{ P-value } \\
\hline Linear & NS & NS & NS & NS & NS & NS & NS & NS & NS & NS & NS \\
\hline Quadratic & NS & NS & NS & NS & NS & NS & NS & NS & NS & NS & NS \\
\hline
\end{tabular}

$V_{l}$ is the volume for the rapid pool (first pool); $k_{l}$ is rate for the rapid pool (first pool); $\mathrm{L}$ is the latency; $V_{2}$ is the volume for the slow pool (second pool); $k_{2}$ is the rate for the slow pool (second pool).

$\mathrm{NS}=$ not significant, $* \mathrm{P}<0.05$ and $* * \mathrm{P}<0.01$. 
The comportment of the gas production curve with include AMZ is presented in Figure $1 b$.

The PRO enzymatic preparation not affected $(P>0.05)$ the gas production parameters and accumulated gas production in of diet containing high level of concentrate (Table 4). The comportment of the gas production curve with include PRO is presented in Figure 1c. Increasing of the dose of $A M Z$ and $\mathrm{PRO}$, resulted in no effect $(\mathrm{P}>0.05)$ on fermentation profile (Table 5).

It may be inferred that the absence of response to amylolytic enzymes adding is due to fact that probably there is no limitation of amylolytic microorganisms and their enzymes on rumen inoculum used in this study. Klingerman et al. (2009), observed in diets dairy cows, apparent digestibility of DM, OM, CP, ADF, NDF and starch not influence with additional inclusion of amylase enzymes (Amaize, Alltech Inc., Nicholasville, $\mathrm{KY}$ ), and those enzymes did not affect milk production. In the studies of Tricarico et al. (2005) and Hristov et al. (2008), amylase enzymes did not affect the digestibility of nutrients in the total tract.

Table 5. In vitro rumen fermentation profile in response to exogenous enzyme dose (mg/ml liquid volume incubated) ${ }^{1}$

\begin{tabular}{|c|c|c|c|c|c|c|c|c|}
\hline Enzyme dosage & $\mathrm{pH}$ & DMD & OMD & $\mathrm{ME}$ & PF96 & GY24 & SCFA & $\mathrm{MCP}$ \\
\hline & \multicolumn{8}{|c|}{ Amylolytic Enzyme } \\
\hline 0.00 & 6.60 & 821 & 0.616 & 9.5 & 2.8 & 263 & 4.78 & 347 \\
\hline 0.05 & 6.67 & 847 & 0.607 & 9.4 & 3.0 & 248 & 4.67 & 384 \\
\hline 0.10 & 6.67 & 833 & 0.613 & 9.5 & 2.9 & 256 & 4.74 & 362 \\
\hline 0.15 & 6.60 & 816 & 0.610 & 9.4 & 2.8 & 260 & 4.70 & 350 \\
\hline 0.20 & 6.63 & 843 & 0.621 & 9.6 & 2.9 & 259 & 4.84 & 362 \\
\hline SEM & 0.026 & 19.367 & 0.024 & 0.365 & 0.045 & 11.362 & 0.298 & 15.263 \\
\hline \multicolumn{9}{|l|}{ P-value } \\
\hline Linear & NS & NS & NS & NS & NS & NS & NS & NS \\
\hline \multirow[t]{2}{*}{ Quadratic } & NS & NS & NS & NS & NS & NS & NS & NS \\
\hline & \multicolumn{8}{|c|}{ Proteolytic Enzyme } \\
\hline 0.00 & 6.60 & 821 & 0.616 & 9.5 & 2.8 & 263 & 4.78 & 347 \\
\hline 0.05 & 6.67 & 826 & 0.604 & 9.3 & 2.9 & 253 & 4.62 & 367 \\
\hline 0.10 & 6.67 & 845 & 0.617 & 9.5 & 2.9 & 256 & 4.79 & 370 \\
\hline 0.15 & 6.63 & 831 & 0.611 & 9.4 & 2.9 & 256 & 4.71 & 364 \\
\hline 0.20 & 6.63 & 841 & 0.613 & 9.5 & 2.9 & 254 & 4.74 & 371 \\
\hline SEM & 0.029 & 18.120 & 0.022 & 0.344 & 0.051 & 10.961 & 0.281 & 15.587 \\
\hline \multicolumn{9}{|l|}{ P-value } \\
\hline Linear & NS & NS & NS & NS & NS & NS & NS & NS \\
\hline Quadratic & NS & NS & NS & NS & NS & NS & NS & NS \\
\hline
\end{tabular}

${ }^{1}$ DMD is dry matter degradability (mg/g DM); OMD is in vitro organic matter digestibility (g/g DM incubated at 24h); ME is metabolisable energy (MJ/kg DM); PF96 is the partitioning factor at $96 \mathrm{~h}$ of incubation (mg DM:ml gas); GY24 is gas yield at $24 \mathrm{~h}$ (ml gas/g DMD); SCFA is short chain fatty acids $(\mathrm{mmol} / \mathrm{g} \mathrm{DM}) ; \mathrm{MCP}$ is microbial CP production $(\mathrm{mg} / \mathrm{g} \mathrm{DM})$.

$\mathrm{NS}=$ Not significant, ${ }^{*} \mathrm{P}<0.05$ and ${ }^{*} * \mathrm{P}<0.01$. 
Thus, it might can be stated that the digestion of starch already happens near to maximum, even when amylolytic enzymes are not supplemented, or occurs a competition for substrate, in which the enzyme may compete with the microbial population for binding sites of the target nutrient, not promoting increase dry matter digestibility (MORGAVI et al., 2000).

It must be emphasized that the main species of rumen amylolytic bacteria also present high proteolytic capacity (RUSSELL, 2002), in order to digest the protein matrix which surrounds the starch granules, especially in the maize and sorghum. In this way it may be infers that the concentration of proteolytic enzymes in the inoculum used in this study was not limiting for digestion of dietary protein, thus helping to explain the lack of response with respect to addition of proteolytic enzymes.

In according with Chen et al. (1995), added a fungal-derived enzyme complex with amylolytic and proteolytic activities, improvement DM, OM, CP, and NDF digestibility, for lactating cows, but did not affect milk production or DMI. Vera et al. (2012) and, Eun \& Beauchemin (2005a) in diet low forage, added protease increase a digestibility of nutrients, but in diet with barley silage or barley dry rolled. However, in studies has different responses, as Colombatto et al. (2003) and, Eun \& Beauchemin (2005b), did not affect with added protease in diets with corn silage, due some fiber components such as lignin can also inhibit specific proteolytic enzymes.

The understanding of the lack of effect for proteolytic enzymes, is not well defined. Several factors may interfere with the effectiveness of the action of exogenous enzymes, being them, differences in enzyme activity, application rate and composition, mode and time of enzymatic contact, ruminal activity in vitro and enzyme stability in this environment, and enzyme-food specificity (BEAUCHEMIN et al., 2004; ADESOGAN, 2014).

The addition of exogenous FIB enzymes improve in vitro gas production and fermentation profile of a mixture of feeds, representing diets containing high levels of concentrates. Increasing the enzyme dose of AMZ increase the accumulated gas production only during the initial times. The PRO enzymes not promote effects on ruminal fermentation in vitro. The authors declare that they have no conflict of interest.

\section{ACKNOWLEDGMENTS}

The authors wish to acknowledge the financial support CAPES (Higher Education Personnel Training Coordination), the Beef Cattle Sector (Federal University of Mato Grosso), and Animal Nutrition Laboratory (Federal University of Mato Grosso).

\section{REFERENCES}

ADESOGAN, A.T.; MA, Z.X.; ROMERO, J.J.; ARRIOLA, K.G. Ruminant Nutrition Symposium: Improving cell wall digestion and animal performance with fibrolytic enzymes.

Journal of Animal Science, v.92, p.1317-1330, 2014.

ASSOCIATION OF OFFICIAL ANALYTICAL CHEMISTS - AOAC. 1990. Official Methods of Analysis. 15th Ed. Arlington 1990.

BEAUCHEMIN, K.A.; COLOMBATTO, D.; MORGAVI, D.P.; YANG, W.Z.; RODE, L.M. Mode of action of exogenous cell wall degrading enzymes for ruminants. Canadian Journal of Animal Science, v.84, p.13-22, 2004. 
BEAUCHEMIN, K.A.; YANG, W.Z.; RODE, L.M. Effects of Grain Source and Enzyme Additive on Site and Extent of Nutrient Digestion in Dairy Cows. Journal of Dairy Science, v.82, p.378390, 1990.

BIELY, P.; MISLOVICOVA, D.; TOMAN, R. Soluble chromogenic substrates for the assay of endo-1,4- $\beta$ xylanases and endo-1,4- $\beta$-glucanases.

Analytical Biochemistry, v.144, p.142146, 1985.

BLÜMMEL, M.; STEINGSS, H.; BECKER, $\mathrm{K}$. The relationship between in vitro gas production, in vitro microbial biomass yield and $15 \mathrm{~N}$ incorporation and its implications for the prediction of voluntary feed intake of roughages. British Journal of Nutrition, v.77, p.911-921, 1997.

CHEN, K.H.; HUBER, J.T.; SIMAS, J.; THEURER, C.B.; YU, P.; CHAN, S.C.; SANTOS, F.; WU, Z.; SWINGLE, R.S. Effect of enzyme treatment or steamflaking of sorghum grain on lactation and digestion in dairy cows. Journal of Dairy Science, v.78, p.1721-1727, 1995.

COLE, N.A.; TODD, R.W.; HALES, K.E.; PARKER, D.B.; BROWN, M.S.; MAcDONALD, J.C. 2012. Nutritional management of feedlot cattle to optimize performance and minimize environmental impact. In: INTERNATIONAL SYMPOSIUM OF BEEF CATTLE PRODUCTION, 4, 2012, Minas Gerais. Proceedings... Minas Gerais. 2012. p.150.

\section{COLOMBATTO, D.; BEAUCHEMIN,} K.A. A proposed methodology to standardize the determination of enzymatic activities present in enzyme additives used in ruminant diets.

Canadian Journal of Animal Science, v.83, p.559-568, 2003.
COLOMBATTO, D.; MORGAVI, D.P.; FURTADO, A.F.; BEAUCHEMIN, K.A. Screening of exogenous enzymes for ruminant diets: Relationship between biochemical characteristics and in vitro ruminal degradation. Journal of Animal Science, v.81, p.2628-2638, 2003.

ELGHANDOUR, M.M.Y.; SALEMA, A.Z.M.; GONZALEZ-RONQUILLOA, M.; BÓRQUEZA, J.L.; GADOB, H.M.; ODONGOC, N.E.; PENUELASA, C.G.

Effects of exogenous enzymes on in vitro gas production kinetics and ruminal fermentation of four fibrous feeds.

Animal Feed Science and Technology, v.179, p.46-53, 2013.

EUN, J.S.; BEAUCHEMIN, K.A. Enhancing in vitro degradation of alfalfa hay and corn silage using feed enzymes. Journal of Dairy Science, v.90, p.28392851, 2007.

EUN, J.S.; BEAUCHEMIN, K.A. Effects of a proteolytic feed enzyme on intake, digestion, ruminal fermentation, and milk production. Journal of Dairy Science, v.88, p.2140-2153, 2005a.

EUN, J.S.; BEAUCHEMIN, K.A.

Exogenous proteolytic enzymes improve in vitro degradation of alfalfa hay but not alfalfa silage. Journal of Dairy Science, v.88, p.316, 2005b. Suppl. 1:

FOOD CHEMICALS CODEX. United States Pharmacopeial Convention. 7th edn.Washington, DC: National Academy Press, 2010. 776p.

GETACHEW, G.; MAKKAR, H.P.S.; BECKER, K. Tropical browses: contents of phenolic compounds, in vitro gas production and stoichiometric relationship between short chain fatty acid and in vitro gas production. Journal of Agricultural Science, v.139, p.341$352,2002$. 
Rev. Bras. Saúde Prod. Anim., Salvador, v.19, n.3, p.287-300 jul./set., 2018 http://dx.doi.org/10.1590/S1519-99402018000300006

GOERING, M.K.; VAN SOEST, P.J. Forage fiber analysis (apparatus, reagents, procedures and some applications). Washington, DC: Agricultural Research Service, 1970. (Agriculture Handbook, 379.).

HALES, K.E.; FOOTE, A.P.; BROWNBRANDL, T.M.; FREETLY, H.C. The effects of feeding increasing concentrations of corn oil on energy metabolism and nutrient balance in finishing beef steers. Journal of Animal Science, v.95, p.939-948, 2017.

HRISTOV, A.N.; BASEL, C.E.; MELGAR, A.; FOLEY, A.E.; ROPP, J.K.; HUNT, C.W.; TRICARICO, J.M. Effect of exogenous polysaccharide degrading enzyme preparations on ruminal fermentation and digestibility of nutrients in dairy cows. Animal Feed Science and Technology, v.145, p.182193, 2008.

KRAUSE, D.O.; DENMAN, S.E.; MACKIE, R.I.; MORRISON, M.; RAE, A.L.; ATTWOOD, G.T.;

MCSWEENEY, C.S. Opportunities to improve fiber degradation in the rumen: microbiology, ecology, and genomics. Microbiological Reviews, v.27, p.663693, 2003.

KLINGERMAN, C.M.; HU, W.; McDONELL, E.E.; DERBEDROSIAN, M.C.; KUNG JUNIOR, L. An evaluation of exogenous enzymes with amylolytic activity for dairy cows. Journal of Dairy Science, v.92, p.1050-1059, 2009.

MAURÍCIO, R.M.; MOULD, F.L.; DHANOA, M.S.; OWEN, E.; CHANNA, K.S.; THEODOROU, M.K. A semiautomated in vitro gas production technique for ruminant feedstuff evaluation. Animal Feed Science and Technology, v.79, p.321-330, 1999.
MAURÍCIO, R.M.; PEREIRA, L.G.R.; GONÇALVES, L.C.; RODRIGUEZ, N.M.; MARTINS, R.G.R.; RODRIGUES, J.A.S. Potencial da Técnica in vitro Semi-Automática de Produção de Gases para Avaliação de Silagens de Sorgo (Sorghum bicolor (L.) Moench). Revista Brasileira de Zootecnia, v.32, n.4, p.1013-1020, 2003.

MENKE, K.H.; RAAB, L.; SALEWSKI, A.; STEINGASS, H.; FRITZ, D.;

SCHNEIDER, W. The estimation of the digestibility and metabolizable energy content of ruminant feeding stuffs from the gas production when they are incubated with rumen liquor in vitro. Journal of Agricultural Science, v.93, p.217-222, 1979.

MONTGOMERY, S.P.; DROUILLARD, J.S.; NAGARAJA, T.G.;

TITGEMEYER, E.C.; SINDT, J.J.

Effects of supplemental fat source on nutrient digestion and ruminal fermentation in steers. Journal of Animal Science, v.86, p.640-650, 2008.

MORGAVI, D.P.; NEWBOLD, C.J.; BEEVER, D.E.; WALLACE, R.J.

Stability and stabilization of potential feed additive enzymes in rumen fluid. Enzyme and Microbial Technology, v.26, p.171-177, 2000.

NAGARAJA, T.G.; TITGEMEYER, E.C. Ruminal Acidosis in Beef Cattle: The Current Microbiological and Nutritional Outlook. Journal of Dairy Science, v.90, p.17-38, 2007.

RANILLA, M.J.; TEJIDO, M.L.; GIRALDO, L.A.; TRICÁRICO, J.M.; CARRO, M.D. Effects of an exogenous fibrolytic enzyme preparation on in vitro ruminal fermentation of three forages and their isolated cell walls. Animal Feed Science and Technology, v.145, p.109121, 2008. 
Rev. Bras. Saúde Prod. Anim., Salvador, v.19, n.3, p.287-300 jul./set., 2018 http://dx.doi.org/10.1590/S1519-99402018000300006

RUSSELL, J.B. Rumen Microbiology and Its Role in Ruminant Nutrition. Ithaca, NY: JB Russell Publishing Co., 2002. p.1-121.

RUSSELL, J.B.; O'CONNOR, J.D.; FOX, D.G.; VAN SOEST, P.J.; SNIFFEN, C.J. A net carbohydrate and protein system for evaluating cattle diets: I. Ruminal fermentation. Journal of Animal Science, v.70, n.11, p.35513561, 1992.

SALEM, A.Z.M.; KHOLIF, A.E.; OLIVARES, M.; ELGHANDOUR, M.M.Y.; MELLADO, M.; ARECE, J.

2014. Influence of S. babylonica extract on feed intake, growth performance and diet in vitro gas production profile in young lambs. Tropical Animal Health and Production, v.46, p.213-219, 2014.

SCHOFIELD, P.; PITT, R.E.; PELL, A.N. Kinetics of fiber digestion from in vitro gas production. Journal of Animal Science, v.72, n.11, p.2980-2991, 1994.

TAJIMA, K.; AMINOV, R.I.; NAGAMINE, T.; MATSUI, H.; NAKAMURA, M.; BENNO, Y. DietDependent Shifts in the Bacterial Population of the Rumen Revealed with Real-Time PCR. Applied and

Environmental Microbiology, v.67, n.6, p.2766-2774, 2001.

TANG, S.X.; TAYO, G.O.; TAN, Z.L.; SUN, Z.H.; SHEN, L.X.; ZHOU, C.S.; XIAO, W.J.; REN, G.P.; HAN, X.F.; SHEN, S.B. Effects of yeast culture and fibrolytic enzyme supplementation on in vitro fermentation characteristics of lowquality cereal straws. Journal of Animal Science, v.86, p.1164-1172, 2008.

TEDESCHI, L.O.; KONONOFF, P.J.; KARGES, K.; GIBSON, M.L. Effects of chemical composition variation on the dynamics of ruminal fermentation and biological value of corn milling (co)products. Journal of Dairy Science, v.92, n.1, p.401-413, 2009.
THEODOROU, M.K.; WILLIAMS, B.A.; DHANOA, M.S.; MCALLAN, A.B.; FRANCE, J. 1994. A simple gas production method using a pressure transducer to determine the fermentation kinetics of ruminant feeds. Animal Feed Science and Technology, v.48, p.185197, 1994.

TRICARICO, J.M.; JOHNSTON, J.D.; DAWSON, K.A. Dietary supplementation of ruminant diets with an Aspergillus oryzae $\alpha$-amylase. Animal Feed Science and Technology, v.145, p.136-150, 2008.

TRICARICO, J.M.; JOHNSTON, J.D.; DAWSON, K.A.; HANSON, K.C.; MCLEOD, K.R.; HARMON, D.L. The effects of an Aspergillus oryzae extract containing alpha-amylase activity on ruminal fermentation and milk production in lactating Holstein cows. Animal Science, v.81, p.365-374, 2005.

UDÉN, P.; ROBINSON, P.H.; MATEOS, G.G.; BLANK, R. Use of replicates in statistical analyses in papers submitted for publication in Animal Feed Science and Technology. Animal Feed Science and Technology, v.171, p.1115, 2012.

VAN SOEST, P.J.; ROBERTSON, J.B.; LEWIS, B.A. Methods for dietary fiber, neutral detergent fiber, and nonstarch polyssacarides in relation to animal nutrition. Journal of Dairy Science, v.74, n.10, p.3583-3597, 1991.

VÁRADYOVÁ, Z; BARAN, M.; ZELENÁK, I. Comparison of two in vitro fermentation gas production methods using both rumen fluid and fecal inoculum from sheep. Animal Feed Science and Technology, v.123-124, p.81-94, 2005. 
Rev. Bras. Saúde Prod. Anim., Salvador, v.19, n.3, p.287-300 jul./set., 2018 http://dx.doi.org/10.1590/S1519-99402018000300006

VERA, J.M.; SMITH, A.H.; ZOBELL, D.R.; YOUNG, A.J.; EUN, J.S. Effects of an exogenous proteolytic enzyme on growth performance of beef steers and in vitro ruminal fermentation in continuous cultures. Professional Animal Scientist, v.28, p.452-463, 2012.

YANG, W.Z.; SON, Y.S.; BEAUCHEMIN, K.A. Effects of Exogenous Enzymes on Ruminal Fermentation and Degradability of Alfalfa Hay and Rice Straw. AsianAustralasian Journal of Animal Sciences, v.24, n.1, p.56-64, 2011.

Receipt date: $12 / 09 / 2017$

Approval date: 11/07/2018 